\title{
Sous l'Egide de la Chronique
}

\author{
CONSTITUTION
}

SOCIETE AMERICAINE DE PHILOSOPHIE DE LANGUE FRANCAISE

\section{Article I. NAME:}

The name of this Society shall be: Société Américaine de Philosophie de Langue Française (American Society of Francophone Philosophy).

\section{Article II. AFFILIATION:}

The Socié Té Américaine de Philosophie de Langue Française was created with the help and with the approval of the Association des Sociétés de Philosophie de Langue Française.

\section{Article III. PURPOSE:}

The Société Américaine de Philosophie de Langue Française is hereby established in order to promote and help foster research on warks by French philosophers as well as encourage the study, dissemination, translation, popularization of these works and the translation into the French language of philosophical works in other languages.

\section{Article IV. INCORPORATION:}

The Société Américaine de Philosophie de Langue Française has been incorporated as a non-profit corporation in, and in accordance with the laws of the State of Illinois, U.S.A.

\section{Article V. MEMBERSHIP:}

There shall be four categories of membership: Regular members, Student members, Life members, and Fellows. The dues structure within each category shall be determined by the Executive Council.

Institutions or organizations wishing to support the Society may 
subscribe to the publications of the Society, but will have no vote in the Society's proceedings.

1. Regular Members. Subject to the approval by an officer of the Society, persons professionally interested in philosophy in the French language may become regular members of the Association.

2. Student Members. Subject to approval by an officer of the Society, graduate students engaged in a course of study leading to a degree in the field of philosophy, or any allied fields, may for a maximum of four years become student members of the Society.

3. Life Members. Persons eligible for regular membership may become life members exempt from annual payment of dues upon a signle payment to be determined by the Executive Committee.

4. Honorary Members and Fellows. Foreign scholars may be elected Honorary members of the Society and distinguished men and women of any nationality may be elected Honorary Fellows.

\section{Article VI. ORGANIZATION:}

1. The administration of the Society shall be in the hands of the Executive Council, consisting of five members, one of whom shall be the President. There shall be two Vice-Presidents of the Society, and a Newsletter Editor. The Secretary-Treasurer shall serve ex-officio. The Executive Council shall act either upon its own initiative or upon the recommendation of the Delegate Assembly.

2. For the conduct of all formal busines of the Society, the authority shall be ROBERT'S RULES OF ORDER NEWLY REVISED (1970).

3. The accounts of the Society shall be audited annually. For budgetary and other administrative purposes, the official year shall be determined by the Council.

4. The permanent Fund of the Association and its other endowment funds as they shall be created shall be administered by a Board of three trustee, each appointed by the Executive Council for a three-year term, the three terms to be staggered by one year. One of the trustees shall be designated the Managing Trustee.

5. The Treasurer shall pay over to the Trustee any sums due the Permanent Fund, either as payments for life membership or as gifts to the 
Society, and also any sums contributed to any other endowment funds. The Trustee shall invest and reinvest the principal unimpaired to the best of their ability. The income accruing on all property in their hands may be reinvested with the authorization of the Executive Council.

6. Any Trustee may be removed by the Executive Council by a unanimous vote or those present at a meeting called for the purpose, and any vacancy arising from the death, resignation, or removal of any Trustee shall be filled by the Council.

\section{Article VII. RESPONSIBILITIES:}

1. The President will preside at all meetings of the Executive Council; the First Vice-President will preside at all meetings of the Delegate Assembly. Either of these duties may be assumed by the President, the First-VicePresident, the Second-Vice-President upon the agreement of these three officers.

2. Under the direction of the Executive Council, the President shall administer the affairs of the Society, with the following specific responsibilities: to be General Editor of all publications issued by the Association; to be exofficio member of all committees and commissions of the Society and chairman of the Program Committee; to act as Secretary of the Executive Council and Clerk of the Delegate Assembly; to have charge of all financial operations of the Society, including the collection of sums due the Society and the payment of its bills; to present to the Council each year a budget for ensuing fiscal year. After action by the Council, the budget shall be distributed to the members of the Association for their information. The President and the Treasurer shall be bonded whenever deemed appropriate by the Executive Council in a sum to be set by said Council.

3. Such administrative, editorial, and clerical assistance shall be provided for the President as may be approved by the Council.

\section{Article VIII. ELECTION:}

1. All officers shall serve for a term of two years.

2. The election of officers will occur during the annual business meeting of the Society and will be settled by a simple majority of the members in attendance, or who have submitted absentee ballots. The Secretary-Treasurer will supervise the balloting and certify the results of the election.

A To provide for its own organization and operations and to 
manage the business and affairs of the Society as provided by the laws of the State of Illinois for directors of Corporation.

B. To act upon recommendations of the Delegate Assembly.

C. To initiate and supervise the services of the Society. expenditure.

D. To approve the budget of the Society and to supervise its

E. To establish and discharge committees and commissions of the Society, either upon recommendation of the Delegate Assembly or upon its own initiative, and to designate their chaimen. In making appointments, the Council shall ensure fair representation of all branches of philosophy.

F. To act upon proposals affecting the dues structure approved by the Delegate Assembly.

G. To supervise publication and other media of the Society.

H. To approve grants and contracts.

I. To plan, with the Program Committee and the Delegate Assembly, the time, place, character, and scope of general conventions and meetings of the Society.

J. To nominate honorary members and fellows.

\section{Article X. EXECUTIVE COUNCIL - COMPOSITION}

The officers named in Article VI shall be the members of the Executive Council ex-officio and two members who are not officers shall be elected to the Executive Council for a term of two years.

\section{Article XI. DELEGATE ASSEMBLY - MEETINGS}

1. There shall be an annual business meeting of the Society, at a time and place determined by the Executive Committee. A notice of the meeting will be prepared by the Program Committee and included in the Society's Newsletter.

2. Special meetings may be called by the Executive Committee.

\section{Article XII. COMMITTEES}


1. Nominating Committee. The Nominating Committee of the Society, charged with nominations for members of the Executive Council, shall be composed of three members who shall serve for two calendars years. In alternate years, one members and two members shall be elected to the Committee.

2. Committee on Resolutions. The Executive Council shall each year appoint a Committee on Resolutions consisting of five members, of whom the Chairman and at least two others shall be members of the Council. Members of this Committee shall be appointed for a term of one year but may be reappointed. They should represent a broad spectrum of the interests of the Society. The Committe shall receive resolutions submitted by members of the Society under the following conditions:

A. No resolution may exceed one hundred words in length.

B. Resolutions submitted to the Chairman of the Committee up to one month before a meeting of Delegate Assembly shall bear the signature of a least ten members.

C. Resolutions submitted to the Chairman of the Committee later than one month before a meeting of the Delegate Assembly at which they are to be presented but not later than forty-eight hours before that meeting shall bear the signature of at least twenty members.

D. No resolution shall be accepted later than twenty-four hours before a meeting of the Delegate Assembly.

E. The Committee may propose resolutions on its own initiative.

F. The Committee shall hold hearings open to all members of the Society on all resolutions it has received and those it has initiated.

G. Taking into account the views expressed at the hearings, the Committee shall evaluate all resolutions submitted to it, as well as those which it has initiated, and shall transmit them to the Assembly meeting, accompanying each resolution with the notation "Recommended" or "Not recommended." from the floor.

H. The Delegate Assembly may not propose new resolutions

I. A majority vote of the Assembly shall be required for 
approval of a resolution. All resolutions so approved must be ratified by a majority of those voting in a mail ballot of the membership of the Association.

3. Committee on Research Activities. The Executive Council shall appoint a Committee on Research Activities. The major fields of philosophy shall always be represented on this committee and its membership shall always include at least one representative from an interdisciplinary field. The committee shall select its own chairman. The duty of this committee shall be to further the research activities of the Society and its members. It shall consider projects of research or publication that may be presented to it, either by individuals, or by the Divisions or by the Societies affiliated to the ASSOCIATION DES SOCIETES DE PHILOSOPHIE DE LANGUE FRANCAISE, and shall report such projects with its recommendations to the Executive Council. It may also initiate projects of research or publication and may authorize grants from the income of the Research Endowment Fund. It may also recommend to the Council the continuation of desirable projects. No research project project undertaken by individual members, by Divisions, or by other scholarly units of the Society or the Association shall be officially sponsored by the Society until it has received the approval of the Committee on Research Activities. This restriction shall not be construed as affecting the authority and functions of other standing committees.

4. Other Committees and Commissions. The Executive Council shall appoint and discharge such other committees and commissions of the Society as it deems appropriate. Membership, term of office, and charge of each committee and commission shall be determined by the Council. The names of committee and commission members and their terms of appointment shall be published at least once a year in an appropriate publication of the Society. Committee and commission members must retain their membership in the Society during their terms of office. The chairman of each committe shall report at regular intervals to the Council on the work of the committee.

\section{Article XIII. CONVENTIONS AND MEETINGS}

1. The Society shall hold one business meeting annually. In an emergency, the Executive Council shall have the power to cancel a convention except for the annual meeting.

2. Conventions shall be planned by the Executive Council with the advice of the Program Committee and Delegate Assembly.

3. The Program Committee shall exercise general supervision over Division and Discussion Groups, making recommendations to the Executive 
Council concerning their number, the fields represented, and policy concerning the conduct of Division and Discussion Group meetings at a Convention. The Executive Director, with the assistance of the Program Committee, shall have final responsibility for planning or approving forums and other special events.

4. The President shall be empowered to make regulations regarding papers and discussions and to coordinate or modify the various Divisions, forums, and Discussion groups in any program until the executive Council meets and acts upon the changes or policies involved.

\section{Article XIV. AMENDMENTS}

Amendments to this constitution may be proposed by petition of any three members of the Society and shall be adopted at the annual business meeting by a two-thirds vote of the members present or submitting verified absentee ballots.

\section{Article XV. DISSOLUTION}

The Society may be dissolved only at a special meeting called for the purpose, and in the manner prescribed by the laws of the State of Illinois, by vote of four/fifths of the members present. Subject to compliance with the applicable provisions of such laws, upon any such dissolution of the Society, all its property remaining after satisfaction of all its obligations shall be distributed to such one or more corporations, funds, foundations, or learned societies, organized and operated exclusively for charitable, scientific, literary, or educational purposes, no part of the net earnings of which inures the benefit of any private shareholder, member, or individual, and which does not carry on propaganda or participate or intervene in any political campaign, as the Executive Council may select. 